\title{
The Effectiveness of Virtual Trials for Criminal Proceeding as an Effort to Mitigate the Spread of Corona Virus During the Covid-19 Pandemic
}

\author{
Fadilla Jamila $^{1 *}$, Melantik Rompegading ${ }^{2}$, Wahyu Hidayat ${ }^{3}$ \\ ${ }^{1}$ Hasanuddin University, Indonesia \\ ${ }^{2}$ Sawerigading University, Indonesia \\ ${ }^{3}$ Belopa District Court, Indonesia \\ *Corresponding author.Email: fadillajamila@gmail.com
}

\begin{abstract}
The first case of Covid-19 in Indonesia was found on 2 March 2020. Although enforcing health protocol is essential in this situation, the law enforcement to the community could not be set aside, especially for criminal proceeding highly related to human rights. Therefore, following the rise of the domestic cases, the Indonesia Supreme Court in cooperation with the Attorney General and the Ministry of Law and Human Rights has agreed to conclude an MOU deciding that during the Covid-19 Pandemic, the criminal proceeding will be conducted through virtual trial to mitigate the spread of the virus. It has been performed for approximately seven months and it is still ongoing. This is not a new practice in our court system as Supreme Court already has the e-court and e-Litigation programs long before the pandemic. Nevertheless, it focused on private proceedings instead of a criminal proceeding and it still has limited roles. This research aims to analyze the effectiveness of virtual trials for criminal proceedings during the Covid-19 pandemic in General Courts by using a normative-empirical approach. The results of the research show that although the criminal proceedings have been conducted through virtual trials, it does not reduce the rights of the accused to seek justice. Furthermore, it has both advantages and disadvantages. Virtual trials help reduce the physical contact in court particularly in criminal proceedings. Thus, it helps mitigate the spread of virus among the judges, court staff, prosecutors, advocates, and the accused. However, the lack of facilities in relevant places such as courts, prosecutor offices, prisons, and detention houses becomes obstacle in carrying out the trial process. Virtual criminal proceedings also make it difficult for public prosecutors, judges, and advocates to gather facts through questions to the accused. Moreover, several aspects should be addressed and improved to provide better legal services to society.
\end{abstract}

Keywords: virtual trial, criminal proceeding, covid-19 pandemic, effectiveness.

\section{INTRODUCTION}

The world has been shocked by the presence of the covid-19 or what is widely known as coronavirus which first appeared at the end of 2019 in Wuhan, China, and rapidly spread all over the world. In response, the National Disaster Management Authority (BNPB) released Decree of the Head of BNPB Number 9.A. 2020 concerning Determination of the status of Emergency Situation caused by CoronaVirus Outbreak which are valid for 32 days from January to 28 February 2020. The first case of covid-19 in Indonesia was found on the $2^{\text {nd }}$ of March 2020. Later on, the decree released by BNPB extended by Decree of the Head of BNPB
Number 13A of 2020 concerning Determination of the status of Emergency Situation of Pandemic Disease caused by Corona Virus Outbreaks, valid for 91 days from 29 February - 29 May 2020 [1]. This emergency status affects many aspects of the country, also an impact on the law enforcement system. The President encourages the country's populatoin to "Stay at home, work from home and pray from home". However, the law enforcement officials could hardly work from home. Law enforcement system, especially the criminal law which is highly related to human rights, has limited period of time to settle. It could not be postponed till the end of pandemic because no one could predict when this pandemic will be over. 
The phrase Fiat Justitia Ruat Coelum, which means 'let the justice be done though the heavens fall' seems to be suitable with the current situation concerning law in the middle of world pandemic, which has been a dilemma. on the one hand, health protocol has to be carried out and the health of the public should be prioritised. On the other, law enforcement could not be set aside and left behind.

On the $13^{\text {th }}$ of April 2020, the Indonesia Supreme Court, in cooperation with the Attorney General and the Ministry of Law and Human Rights, have agreed to conclude a Memorandum of Understanding (MOU) deciding that during the Covid-19 Pandemic criminal proceeding will be conducted through virtual trial to mitigate the spread of the virus [2]. The virtual trial is not a new practice in the Indonesian court system. Supreme Court already established the e-court and elitigation programs back in 2019. However, these programs could only be applied for private matters and it is not applicable for criminal cases. The ECourt is a service that could be used by registered users for online case registration (e-filling), obtaining estimated court fees, and conducting online payments (e-payment), summons made by electronic channels (e-summon), and electronic trials (e-litigation) [3]. Through e-c, the submission of trial documents such as Replicate, Duplicate, Conclusions and/or Answers can be exercised online and these documents will be accessible by the Court and the parties. Thus, the process of resolving cases at court is no longer always carried out in a conventional way, where the parties must come directly to the trial in the court [4].

In the criminal law area, the virtual proceeding has also been regulated and implemented in terms of examination of the witnesses. It is ruled within Law No.13 of 2006 concerning the Protection of witnesses and victims. According to articles 9 (3) and (1), the testimony of the witnesses could be heard through electronic media accompanied by the authority and it is conducted if the witnesses feel threatened.

Article 1 (12) of the Supreme Court Regulation No.4 of 2020 concerning Administration and Trial of Criminal Cases in Court Electronically defined virtual trial as a series of processes to examine, hear and decide the case of the accused by the court, which was carried out with the support of information and communication technology, audiovisual and other electronic means. It has been implemented for approximately seven months and it is still receiving some critics. This paper will analyze the implementation of virtual trials for criminal proceedings during the covid-19 pandemic and analyze how effective it is in mitigating the spread of the virus. The findings of this research will be divided into five parts. The first one is regarding the fulfillment of the rights of the accused during the virtual criminal proceeding. The second will discuss the implementation of Criminal Procedural Law during the virtual trial. The third part will analyze the weaknesses of virtual trials. Meanwhile, the fourth part will analyze the advantage of virtual trials in mitigating the spread of the coronavirus during the pandemic. The last part will propose matters that need to be improved concerning the exercise of the criminal virtual trial.

\section{RESEARCH METHODS}

The method used in this research is normativeempirical legal research (applied law research). The main point of the study is the implementation of procedural law provisions in the practice of criminal virtual trials. Data were obtained using questionnaires from respondents consisting of parties involved in online criminal proceedings including judges, prosecutors, advocates, and staffs of prisons and detention centres. The secondary data used were obtained from literature studies such as laws, government regulations, literature, and other scientific documents. The data were analyzed in a logical and normative manner and then described qualitatively. The questionnaires, made available to complete using google form, consist of two question types. Closed questions limit the options of the answer into certain categories, while the open questions allow the respondents to share their experiences in a more elaborating way. The following table shows the number of our respondents according to their respective professions:

\begin{tabular}{|l|l|c|}
\hline No. & Professions & $\begin{array}{l}\text { Total of } \\
\text { Respondents }\end{array}$ \\
\hline 1. & Judges in District Courts & 63 \\
\hline 2. & Prosecutors & 14 \\
\hline 3. & Advocates & 19 \\
\hline 4. & Staffs of Detention Centres & 9 \\
\hline \multicolumn{2}{|l|}{} & 105 \\
\hline
\end{tabular}

Figure 1-Data of Respondents 


\section{FINDINGS AND DISCUSSIONS}

\subsection{The fulfillment of rights of the accused during the virtual criminal proceeding}

The essence of the judicial process is the enforcement and protection of human rights for the victim, the accused and the community in general. For victims, a fair trial process will guarantee the protection of their rights and interests which have been violated by the Defendant. For the Defendant, a legal trial process will provide protection for their rights not to be tried arbitrarily. While for the general public, judicial process provides legal certainty and guarantees that any action that threatens public order and peace will be acted upon in accordance with applicable legal norms.

With the enactment of Law Number 8 of 1981 concerning Criminal Procedural Law or commonly referred to as KUHAP, apart from being the basis for criminal procedural law in Indonesia, its content becomes a solid foundation in upholding the human rights of the Defendant within the judicial process. This is because the content of the Criminal Procedural Code protects the interests of the defendant more than the interests of the victim, let alone the general public. From the perspective of upholding the defendant's rights, this is a positive step because the Defendant will receive legal certainty. The law ensures that the defendant will face a fair trial process which is free from arbitrary behaviour by law enforcement officials.

In conducting online criminal proceedings as a form of adaptation to the Covid-19 pandemic situation, it is a challenge for all law enforcement officials, especially the court, to what extent the rights of the Defendant can be consistently enforced as regulated in the Criminal Procedure Code as if it were a direct trial. Essentially, the implementation of online criminal proceedings is an effort by courts and other law enforcement institutions to fulfill one of the basic rights of the Defendant as referred to in Article 50 paragraph (3) of the Criminal Procedure Code, namely the right to be tried by the Court immediately despite the emergency of Covid-19 pandemic, where all activities involving large groups of people should not be permitted due to the potential to increase the risk of transmission of the virus. If we refer to the conventional trial procedures as regulated in the Criminal Procedure Code, the trial process shall not be carried out during the pandemic and we have to wait until the pandemic ends. However, the problem is that no party or institution can provide certainty about when the pandemic will end, while Defendants have the right to be tried for his/her case immediately. Therefore, departing from the principle that courts are obliged to assist justice seekers and try to overcome all obstacles to realize a simple, fast, and low-cost trial, the Supreme Court issued Supreme Court Regulation Number 4 of 2020 concerning Administration and Trial of Criminal Cases in Courts electronically which is the basis to conduct criminal virtual trials.

However, the enforcement of the Defendants' rights during criminal virtual trials will certainly be different from conventional trials as it is enforced in the Criminal Procedural Code. For example, article 51 paragraph 2 of the Criminal Procedure Code stipulated that the defendant has right to be clearly informed in a language he/she understands about what he/she is accused of. Although before the trial commences the Defendant receives a copy of the indictments from the public prosecutor, sometimes the Defendant does not fully understand the indictment letter submitted to him. Thus, the defendant still needs an explanation directly from the Public Prosecutor in the trial. In a live trial, the Public Prosecutor could easily convey his explanation directly to the Defendant, whereas it is not the same case during the online trial where the Defendant, the Panel of Judges, and the Public Prosecutor are in different room.. In this condition, the explanation of the indictment submitted by the Public Prosecutor may not be properly accepted and understood by the Defendant.

Nevertheless, the other rights of the Defendants during the online trial could still be fulfilled as in conventional trials. For example, the right of the Defendant not to be presumed guilty before a Judge's decision has the permanent legal force to declare his guilt. Additionally, the right of the defendant to provide information freely as stipulated in Article 52 of the Criminal Procedural Code can still be enforced even though the trial is conducted online. In other words, the use of electronic media should not restrict the defendant from giving information freely, even though technical or network disruption may somewhat affect the communication between the Defendant and the Panel of Judges.

Another example is that the right to be assisted by Legal Counsel can still be fulfilled [5]. According to article Article 2 paragraph (2) of Supreme Court Regulation No. 4 of 2020, in the event that the trial is determined to be held electronically, the Defendant shall be accompanied 
by his Legal Advisor at the place where he is detained, or if the defendant is not detained, he/she may attend the trial in the courtroom or the office of the Prosecutor accompanied by his Legal Counsel if the defendant chooses or is provided with the assistance of legal advisor during his trial. Therefore, it can be concluded that the rights of the defendant are still fulfilled even though the proceeding is held virtually.

\subsection{The Implementation of Criminal Procedural Law during Virtual Trial}

In normal situation, the Criminal Procedural Code, which served as the basis of procedural law, must be applied strictly and cannot be distorted as the procedural law is rigid. However, during the covid-19 pandemic which forces the trial to be held virtually, the application of the Criminal Procedural Code cannot be implemented properly. Several procedural law provisions in the Criminal Procedural Code are impossible to apply within the current situation. The first example is that according to Article 230 paragraph (1) of the Criminal Procedural Code, a court session shall be held in a court building inside a courtroom. In fact, during the virtual trial, the proceeding is not only held in the courtroom, but also in the Prosecutor's office building where the Public Prosecutor participates in a trial via teleconference. The defendant, however, participates from either the prison building, the State Detention Centre, or Police Station. The second one is the application of Article 160 of the Criminal Procedural Code which requires witnesses to be presented physically into the courtroom. In the practice of online trials, the acharge witness attends the trial from where the Public Prosecutor attends the trial, while the a-decharge witness attended the trial from the place where the Legal Counsel / Defendant attended the trial.

To fill the legal void, the Supreme Court then issued Supreme Court Regulation Number 4 of 2020 concerning Administration and Trial of Criminal Cases in Court Electronically. Within its preamble, it is explained that the background for the establishment of this regulation began from the consideration that the court is obliged to assist justice seekers and strive to realize a simple, fast, and low-cost trial. Thus, it can be understood that the provisions in the Criminal Procedural Code that can hinder the implementation of the judicial process during the pandemic, such as Article 230 paragraph (1) and Article 160 of the Criminal
Procedural Code, can be resolved through this regulation. This is reasonable because the Criminal Procedural Code only regulates the proceedings under normal situations. At the time of its formation, the legislators would never have imagined that someday the community would face a pandemic situation like today.

In the hierarchy, the position of the Supreme Court regulations is far below the criminal procedural code which is a classified as an act. As a consequence, it is inappropriate for the Supreme Court Regulation to override the provisions of criminal procedural code. But based on the legal principle of salus populi suprema lex esto where people's safety is the highest law, it becomes reasonable to implement the provisions within the Supreme Court Regulation instead of the Criminal Procedural Code as long it aims to mitigate the spread of the virus and protect the society.

The most essential breakthroughs in that Regulation is the introduction of electronic courtroom terminology. This expands the scope of the courtroom not only in the court building as referred to in Article 230 paragraph (1) of the Criminal Procedural Code, but also includes the prosecutor's office, detention centre/prison offices, or other places determined by the Judge. In that sense, the Public Prosecutor and the Defendant no longer have to appear face to face in the courtroom during the proceeding as but the trial can be carried out from their respective residence or office.

Supreme Court Regulation No. 4 of 2020 should be considered as the "emergency procedural law" during a pandemic. Although the scope of electronic trial arrangements in this regulation is not limited only to situation during the covid-19 pandemic but also includes other situations where it is not possible to carry out ordinary judicial processes. These types of situations include natural disasters, any emergency situation determined by the government, or other circumstances which according to the decision of the Panel of Judges it is necessary to conduct the trial electronically.

\subsection{The weaknesses of a virtual trial}

Based on the recently gathered data, several weaknesses have been found during the implementation of criminal virtual trial, as discussed in the subsequent sections. 


\subsubsection{Poor Internet Connection}

Internet Connection is a crucial element in conducting a virtual proceeding. It is the main resource that keeps all the relevant parties connected. However, the majority of the respondents who are law enforcement officials involved in virtual trials complained about the poor connection. (see figure 2)

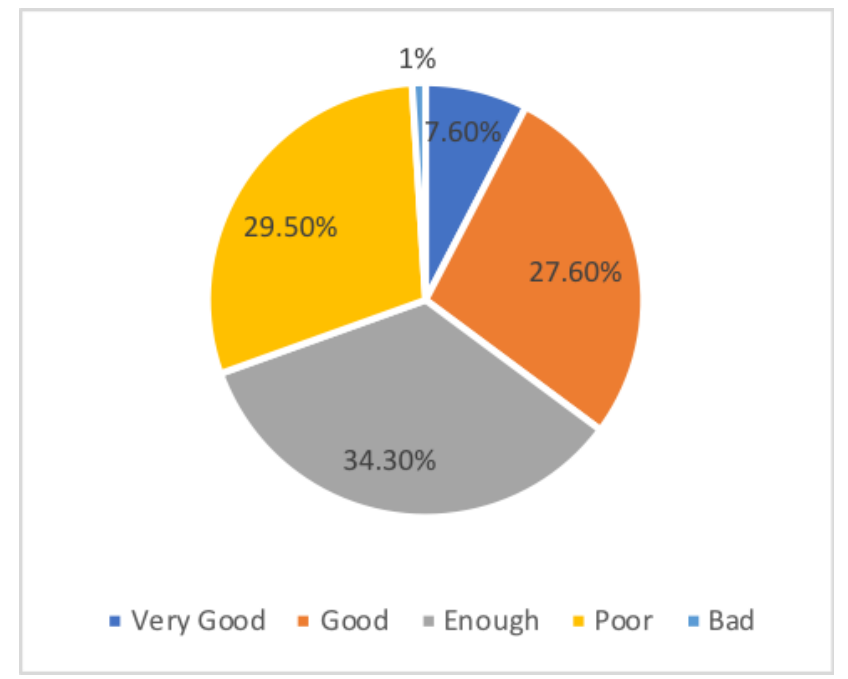

Figure 2 - The quality of supporting facilities and infrastructures to conduct virtual trial

The poor internet connection in either courtroom, prosecutor's offices, prisons, detention centers, or any other relevant places could interrupt the whole process of proceedings [6]. As a result, the communication between the respective parties may bedisrupted. This leads to difficulties in exploring facts from the trial. The sudden loss of internet connection often disturbs the concentration of the parties. Thus, sometimes the questions or the statements need to be repeated and it is not time efficient. Often, the proceedings have to be delayed or even postponed due to unstable internet connection from any of the respective parties, causing it to become inefficient.

\subsubsection{Inadequate facilities and infrastructure}

The practice of a virtual trial is not the same as in the conventional one, where all the parties gather in the same courtroom. In a criminal virtual trial, the judges and the prosecutors will be in the courtroom and in their office respectively, while the accused will be in either a prison, detention center, or a police station. Therefore, appropriate and suitable facilities and infrastructure that support the technology will be needed to connect the parties and to make sure that all of them could communicate optimally by being able to see and hear each other. Several facilities and infrastructure that are essential in this process Include laptop or LED TV, camera, microphone, and speaker. However, it is well-known that many of the respective places are not in possession of these facilities and infrastructures.

Many General Courts in Indonesia only have one room that supports trial via teleconference. As a result, panels of judges have to take a turn to use this teleconference room in conducting a trial.

Another issue arose when the accused is detained in several different places. For instance, some defendants are detained in either prisons or detention centers while some others are detained in police stations. In conducting virtual trials, police stations are claimed to be less prepared when compared to the other relevant places. In that sense, some of them do not have a special room to conduct virtual proceeding, which results in disruptive noises during the virtual trial. Also, often they also do not have appropriate or adequate equipment.

\subsubsection{Limited Human Resources}

Human resources capable of operating technology are needed to conduct a virtual trial. However, some of the respondents have claimed that they still face difficulty on this matter. Not all respective institutions have decent resources, particularly during the period when virtual trials were first implemented.

\subsubsection{Problems during Evidence Examination}

Verification of evidence provides certainty towards judges regarding the legal actions through certain evidence/tools to grant the indictments related to those legal actions [7]. This process is carried out by submitting evidence and according to article 184 of the Criminal Procedural Code, the legitimate evidence in criminal cases consists of witness statements, expert statements, letters, instructions, and statements of the Defendant. A judge should not impose a sentence on a person unless, with at least two valid pieces of evidence, he is convinced that a criminal act occurred and that the defendant is guilty of committing it (Article 183 of Criminal procedural Code). Besides the evidence tools that have been mentioned, in criminal law, the term evidence goods is also known. The definition 
of evidence good is not explicitly mentioned in the Criminal Procedural Code. However, article 39 (1) of the Criminal Procedural Code implicitly provides definitions of evidence good as good that is directly related to the criminal act that occurred. It consists of goods or claims which are entirely or partly suspected to have been obtained from a criminal act, objects used to commit a criminal act, obstruct a criminal investigation, or specially made or intended to commit a criminal act.

The procedure for submitting evidence has been stipulated in Article 184 to article 189 of the Criminal Procedural Code. However, in the virtual trial mechanism as regulated in Supreme Court No. 4 of 2020, the evidentiary procedure has shifted according to the adaptation of new habits.

The first one is regarding the examination of witnesses and experts. According to article 185, a witness's testimony as evidence is what the witness stated in court. This provision requires that the witness be physically present in the courtroom to convey information. As for the expert. based on article 186 of the Criminal Procedure Code, an expert's statement is what an expert states during the proceeding in the court. Nevertheless, article 11 of the Supreme Court Regulation No.4 of 2020 expands the scope. It is no longer limited to testimony given in the courtroom, but also the witness and expert could be examined and give their testimonies via teleconference from the prosecutor's office within the area of court's jurisdiction. The courts are in either inside or outside the jurisdiction of the court handling the case, embassy/consulate general of the Republic of Indonesia with the approval/recommendation of the minister of foreign affairs if the witness or expert reside overseas, or in other places determined by the judges.

Examining witness and expert during the virtual trial has several weaknesses. The main problem that is found is that the poor internet connection causes the examination to be less effective. This disruption could psychologically affect the judge in examining the facts in every witness. Judges tend to ask standard questions only to fulfil the elements of the article indicted. Whereas article 185 of the Criminal Procedural Code mandates that in assessing the truth of the testimony of a witness, there are several aspects that should be considered by the judge. Those aspects consist of the conformity between the testimony of a witness to another, compatibility between the testimony of the witness and the evidence, reasons which may be used by the witness in giving the testimony, the witness's way of life and morals, as well as anything in general that may affect whether the testimony is trustworthy.

Another problem that can occur during the examination of witnesses or experts is that it is difficult for the Judge to assess the witness's psychological expression and gesture considering that he may be under pressure in giving testimony, or that he may be directed by another person in providing information. This can certainly affect the objectivity of the witness in giving testimony. In this regard, the purpose of criminal procedural law to realize material truth may not be fulfilled.

Furthermore, regarding the examination of the defendant, it is the same as the examination of witnesses and experts. Examination of the defendant as referred to in Article 189 of Criminal Procedural Code requires the physical presence of the Defendant in the courtroom. Whereas in the virtual proceeding, according to article 13 (2) of Supreme Court Regulation No.4 of 2020, the defendant who is in detention will be examined from the place where he/she is being detained or from the prosecutor's office. Problems that can arise are similar to the problems of examining the witness and expert. For instance, the examination does not run optimally due to poor internet connection and it isdifficult to assess whether the defendant is under pressure or not. Furthermore, there is also a possibility that the defendant is being directed by his/her legal advisor in answering the questions and it is missing from the observation of the Judge and Prosecutor.

Finally, the submission and the examination procedure of documentary evidence and any other evidence good in a virtual proceeding is quite different from the conventional one. In a conventional trial, letters and evidence are submitted directly to the court and examined directly before the Judge / Panel of Judges, while in a virtual trial, based on Article 14 of Supreme Court No. 4 of 2020, the delegation is performed electronically. The evidence to be examined remains at the prosecutor's office. Then in the examination session, the prosecutor virtually shows the evidence to the Judge/panel of judges and the Defendant. The weakness of this type of procedure is the low level of accuracy of judges in viewing and examining evidence in detail. To examine the evidence submitted, the Judges need to be careful during examination to avoid manipulation of the evidence by the Prosecutor. False evidence may 
appear in trial and injure the rights of the Defendant.

\subsection{The advantages of virtual trial}

From the questionnaire, the majority of the respondents believe that criminal virtual trials are certainly helpful to mitigate the spread of the coronavirus during the covid-19 pandemic (see figure 3). According to the supreme court annual report, in 2018 there are 5,434,793 criminal cases submitted to the general courts, while only 106,181 private law cases were submitted [8]. It shows that the number of criminal cases handled by the general court is 54 times higher than those of private law cases. Thus, the decision to conduct the criminal proceeding in the form of a virtual trial is helpful to significantly reduce the number of daily visitors to general courts. It helps to reduce the number of direct meetings among the respective parties that could potentially become the media of transferring the virus. Virtual trials also maintain physical distancing and avoid the large crowds, an effort highly recommended both by the World Health Organization and the Ministry of Health of the Republic of Indonesia.

Virtual proceeding as an effort to mitigate the spread of the coronavirus is not only carried out in Indonesia [9]. Some of the countries that implement virtual proceedings include Malaysia, China, the United Kingdom, the United States of America, and many other countries. The problems that have been previously discussed are not only faced by Indonesia but also in many other countries [10]. It is reasonable because the appearance of the virus is unpredictable and it urged countries to adjust immediately to protect public health.

Although the implementation of virtual trials during the covid-19 pandemic has not been fully successful to avoid the spread of the coronavirus in our juridical environments, it helps reduce the number and avoid the massive widespread. According to data from Supreme Court concerning Covid-19 cases within the Indonesian judicial environment, as for $22^{\text {nd }}$ October 2020, 139 staff have been treated, 483 are in self-isolation, 233 have recovered from the virus, and 11 died [11]. The virtual trial may not be able to fully protect the law enforcement officials or justice seekers from being infected with this virus. Because there are still other possibilities for the virus to spread, such as during the private case trials, daily interactions with co-workers or with any other people outside of work, and many others. The implementations of virtual trials have attempted to reduce the spread of the virus.

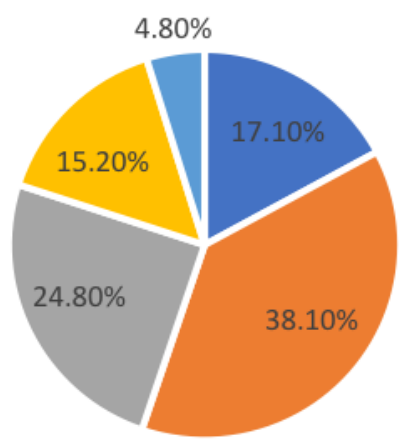

$$
\begin{aligned}
& \text { - Very Effective - Effective }=\text { Enough } \\
& \text { = Less effective - Not effective }
\end{aligned}
$$

Figure 3 - Effectiveness of Criminal Virtual Trials to Mitigate the Spread of The Corona Virus during the Covid-19 Pandemic

\subsection{Matters to be improved concerning the exercise of virtual trial}

According to the results of the research, several aspects need to be improved to effectively implement the criminal virtual trial. The first is to improve the facilities and infrastructure in relevant places where the virtual trial is conducted, such as courts, prosecutors' offices, prisons and detention centers, advocates' offices as well as police stations in certain cases. Facilities and infrastructures are essential parts to perform virtual trials [12]. It has been ruled under Supreme Court Regulation No.4 of 2020 that during the virtual trial, all trial participants must be seen and heard clearly. However, it could not be achieved without proper facilities and infrastructures, thus improvement and procurement of relevant facilities are urgently required. Besides, standardization is also needed so that all areas in Indonesia could provide an optimal legal service. The rural area should not be left behind and extra attention is needed. The quality of internet connection in respective places should be improved to support the efficiency of virtual trials.

Secondly, the human resources in all elements involving in the process of virtual trials need to be improved, particularly the resources with a comprehensive understanding of the use of technology, which is a fundamental element in the process of virtual trials. It is due to the shifted of the current demands of the expansion of technology 
particularly during the implementation of virtual trials. This aspect could be improved by conducting specific training related to the process of virtual trial particularly in preparing the technology and operating the equipment of virtual trial. Alternatively, the respective institutions could recruit staffs that have a specialization in the field of information and technology (IT) so that the institutions will be more prepared in conducting virtual trials.

\section{CONCLUSIONS}

Virtual trials for criminal proceedings in Indonesia have been implemented for approximately seven months. It has raised some questions, particularly those regarding the fulfillment of the rights of the defendant. This research found that the fulfillment of rights of the defendants during the virtual trial is not as effective as it is in a conventional trial. However, their rights are still fulfilled although the proceeding takes place via teleconference. In the case of criminal procedural law, it is still implemented effectively despite some adjustments that have to be made to adapt to the current situation. Supreme Court Regulation No.4 of 2020 concerning Administration and Trial of Criminal Cases in Court Electronically has fulfilled the loophole of the current situations where some provisions of the Criminal Procedural Code are not possible to be implemented.

It has to be admitted that the implementation of virtual trials for criminal proceedings during the covid-19 pandemic in Indonesia still faces many problems. The main problems consist of the poor internet connection, inadequate facilities and infrastructures, limited human resources, and difficulties during the evidence examination. However, it is so far the most realistic and effective way to mitigate the spread of the coronavirus in our judicial environment. Virtual trials claimed to be effective in reducing the number of direct meetings between the parties that could potentially become the medium of virus transmission. It also promotes physical distancing and avoids large crowds by allowing the respective parties to attend the proceeding in their premises and offices. Nevertheless, some improvements still need to be made to perform more effective virtual trials, such as improving the facilities and infrastructures, including internet connection as well as developing the human resources.

\section{REFERENCES}

[1] D. Arifin, "Status Keadaan Tertentu Darurat Bencana Wabah Penyakit Akibat Virus Corona di Indonesia," Badan NAsional Penanggulangan Bencana, 2020. [Online]. Available: https://bnpb.go.id/berita/status-keadaantertentu-darurat-bencana-wabah-penyakitakibat-virus-corona-di-indonesia-.

[2] M. Agung, K. R. Indonesia, and K. Hukum dan Ham, "Perjanjian Kerjasama Antara Mahkamah Agung Republik Indonesia, Kejaksaan Republik Indonesia dan Kementerian Hukum dan Hak Asasi Manusia Republik indonesia.” 2020.

[3] M. Agung, "Buku Panduan e-Court Mahkamah Agung 2019: The Electronic Justice System," Mahkamah Agung Republik Indones., pp. 1-84, 2019.

[4] S. Retnaningsih, D. Latifah, S. Nasution, and R. Anita, "Pelaksanaan E-Court Menurut Perma No. 3 Tahun 2018 Tentang Administrasi Perkara Di Pengadilan Secara Elektronik Dan E-Litigation Menurut Perma Nomor 1 Tahun 2019 Tentang Administrasi Perkara Dan Persidangan Di Pengadilan Secara Elektronik (Studi di Pengad," J. Huk. Pembang., vol. 50, no. 1, pp. 124-144, 2020.

[5] F. R. Shiddiq and S. Harahap, "Perlindungan Hukum atas Hak Terdakwa untuk Didampingi Penasehat Hukum dalam Mememenuhi Hak Hak Terdakwa Legal Protection of The Right of Accused to Be Accompanied by A Legal Counsel in Fulfilling The Rights of The Accused," Pros. Ilmu Huk., vol. 4, no. 2, pp. 696-702, 2018.

[6] Pengadilan Negeri Kotamobagu, "Laporan Monev Penyelenggaraan Peradilan pada Pengadilan Negeri Kotamobagu Dalam Masa Penyebaran Corona Virus Disease 2019 (Covid-19) Periode Januari-Mei 2020," 2020.

[7] A. Ali and W. Heryani, Asas-Asas Hukum Pembuktian Perdata. Jakarta: Kencana, 2012.

[8] Tim Pokja Laporan Tahunan MARI, "Laporan Tahunan 2018 Mahkamah Agung," 2019.

[9] S. Handika et al., "Virtual Court Policy For Criminal Justice on Corona Virus Disease Pandemic," Subtantive Justice Int. J. Law, vol. 3, no. 1, pp. 74-93, 2020.

[10] A. D. Lumbanraja, "Perkembangan Regulasi dan Pelaksanaan Persidangan 
online Di Indonesia dan Amerika Serikat Selama Pandemi Covid-19," J. Crepido, vol. 02 , no. 01 , pp. 46-58, 2020.

[11] Mahkamah Agung, "Website Informasi Sebaran Covid-19 di Lingkungan Peradilan." [Online]. Available: https://corona.mahkamahagung.go.id/tracki ng.
[12] A. A. Sodik, "JUSTICIABELEN: Penegakan Hukum di Institusi Pengadilan dalam menghadapi Pandemi Covid-19," Khazanah Huk., vol. 2, no. 2, pp. 56-64, 2020. 